\title{
Analisis Spesialisasi dan Konsentrasi Spasial Industri Manufaktur di Provinsi Jawa Timur
}

\author{
Syamsul Ma'arif ${ }^{1}$, Duwi Yunitasari ${ }^{2^{*}}$, Regina Niken Wilantari ${ }^{3}$ \\ 1,2,3 Jurusan Ilmu Ekonomi Studi Pembangunan, Fakultas Ekonomi dan Bisnis, Universitas Jember \\ Jln. Kalimantan 37, Jember 68121 Indonesia \\ *e-mail:duwiyunitasari.feb@unej.ac.id
}

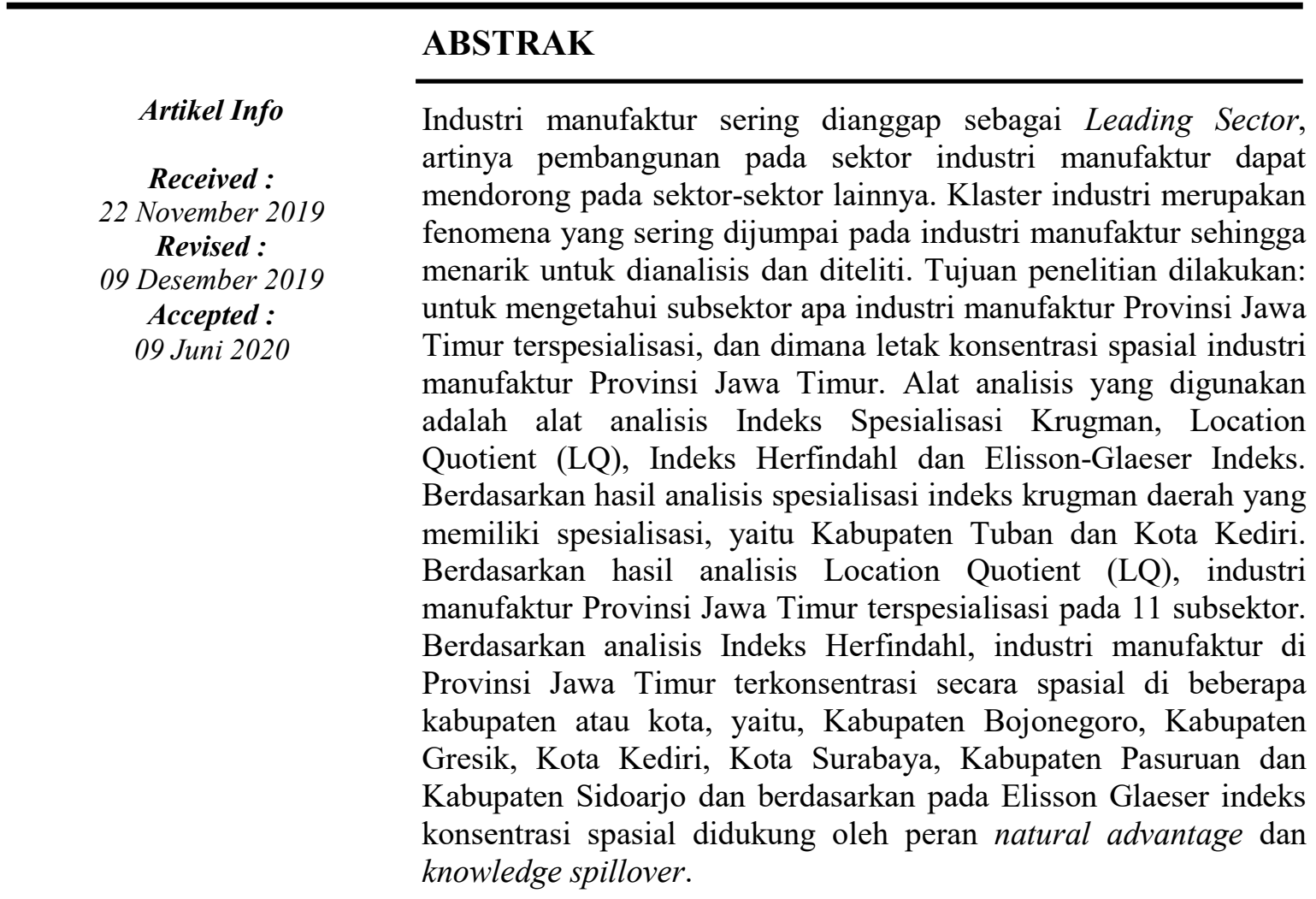

Kata Kunci : Industri Manufaktur, Spesialisasi, konsentrasi Spasial.

\section{Analysis of Specialization and Spatial Concentration of Manufacturing Industries In East Java Province}

\section{ABSTRACT}

Industrial cluster is a phenomenon that is often found in the manufacturing industry so it is interesting to be analyzed and researched. The purpose of this study is to determine in what subsectors the manufacturing industry in East Java Province is specialized and where is the spatial concentration of the manufacturing industry in East Java Province. This study uses analysis tools, Krugman Specialization Index, Location Quotient (LQ), Herfindahl Index and Elisson-Glaeser Index. Based on the 
results of the analysis of the specialization of the regional krugman index that has specialization, namely, Tuban Regency and the City of Kediri. Based on the results of the Location Quotient (LQ) analysis, the manufacturing industry of East Java Province specializes in 11 subsectors. Based on the analysis of the Herfindahl Index, the manufacturing industry in East Java Province is spatially concentrated in several districts or cities, namely, Bojonegoro Regency, Gresik Regency, Kediri City, Surabaya City, Pasuruan Regency and Sidoarjo Regency and based on the Elisson Glaeser index the spatial concentration is supported by the role of natural advantage and knowledge spillover.

Keyword : Cluster, Manufacturing Industry, Specialization, Spatial Concentration.

\section{PENDAHULUAN}

Konsep pembangunan dan proses industrialisasi seringkali dikaitkan karena itu pengertian keduanya sering disamaartikan, Industri dapat dikatakan sebagai Leading Sector, artinya dampak dari pembangunan sektor industri dapat meningkatkan pembangunan sektor-sektor lain seperti sektor pertanian, jasa-jasa, dll. Salah satu dari pelaksanaan Garis Besar Haluan Negara (GBHN) untuk mencapai target pembangunan jangka panjang yaitu, pembangunan industri yang bertujuan untuk kemandirian Indonesia untuk meningkatkan kekuatan dalam negeri yang berdasarkan Pancasila dan UUD 194 (Arsyad, 1999).

Di Indonesia, pembangunan ekonomi yang awalnya didominasi oleh sektor pertanian dalam mencapai swasembada (Yunitasari, 2019), mulai tergeser oleh sektor industri manufaktur. Hal ini terjadi karena pembangunan sektor industri manufaktur sangat cepat di Indonesia. Pembangunan sektor Industri mengakibatkan struktur perekonomian Indonesia berubah yang awalnya berbasis pertanian menjadi berbasis industri (Hill, 2000 dalam Kuncoro, 2007).

Pemerintah pusat dan daerah perlu didukung dengan serangkaian kebijakan dalam hal merumuskan dan mengimplementasikan kebijakan di sektor industri manufaktur, yaitu kebijakan yang berorientasi spasial dan regional (Kuncoro, 2002). Pada tahun 2000, kebijakan nasional dan regional sektor industri manufaktur telah diberikan perspektif dan pendekatan klaster guna mendorong spesialisasi serta meningkatkan produktivitas dan efisiensi.

Salah satu ciri yang menonjol dari industri manufaktur adalah proses klaster (clustering), baik industri besar dan menengah (IBM) maupun industri kecil dan rumah tangga (IKRT). Klaster adalah konsentrasi geografis dari subsektor-subsektor industri yang sama (kuncoro, 2007). Porter (dalam Kuncoro, 2007) mengatakan para kompetitor pada banyak industri, dan bahkan seluruh klaster industri yang sukses untuk skala internasional ternyata sering terjadi hanya di beberapa kota atau beberapa daerah saja dalam suatu negara. Pembangunan industri dan aktivitas bisnis di Indonesia selama ini selalu terjadi di pulau Jawa dan pulau Sumatera. Sejak tahun 1990-an, industri manufaktur di Indonesia hanya terkonsentrasi spasial di Pulau Jawa saja (Aziz, 1994; Hill, 1990 dalam Kuncoro, 2007).

Provinsi Jawa Timur memberikan kontribusi terhadap PDB sektor Industri Manufaktur terbesar ke dua, rata-rata Rp. 492.346,4 miliar dan peningkatan dari tahun ke 


\section{EKONOMIKAWAN : Jurnal Ilmu Ekonomi dan Studi Pembangunan}

I55N : $1693-7600$ (print), 155N : 2598-0157 (Online), hutp://rumal.umstiac.id//ndex,php/ekawan

tahun yang tertinggi dengan rata-rata peningkatan kurang lebih Rp. 50.000 miliar setiap tahunnya. Perekonomian Provinsi Jawa Timur mengalami peningkatan dalam kurun tahun 2013-2017, dimana industri manufaktur memiliki peranan tertinggi dalam PDRB Jawa Timur setiap tahunnya dengan kisaran Rp. 345.794,60 miliar sampai Rp. 434.130,80 miliar, diikuti dengan sektor perdagangan, transportasi dan pergudangan diurutan ke dua dan sektor pertanian, kehutanan, dan perikanan diurutan ke tiga (BPS, 2018).

Untuk terus meningkatkan serta mengembangkan perekonomian daerah, Pemerintah Provinsi Jawa Timur harus menyusun kebijakan untuk industri manufaktur agar dapat berkembang. Kebijakan industri dengan pendekatan klaster dianggap paling efektif untuk menekan biaya produksi serta meningkatkan daya saing industri manufaktur guna mempertahankan atau bahkan memperluas pemasaran. Industri manufaktur memerlukan sarana agar dapat mengembangkan diri dan bersaing untuk menghadapi perdagangan bebas saat ini. Tujuan penelitian ini untuk mengetahui spesialisasi industri manufaktur Provinsi Jawa Timur serta letak konsentrasi spasial dari industri manufaktur.

\section{METODE}

Metode yang digunakan dalam penelitian ini merupakan metode deskriptif kuantitatif yaitu, penelitian yang menggunakan data yang diperoleh dari sampel atau populasi yang dianalisis sesuai dengan metode statistik yang digunakan. Penelitian deskriptif digunakan untuk melihat spesialisasi dan konsentrasi spasial industri manufaktur di Jawa Timur.

Penelitian ini menggunakan data sekunder. Data sekunder yang digunakan yaitu data Produk Domestik Regional Bruto (PDRB) Provinsi Jawa Timur dan Kabupaten atau Kota di Jawa Timur dengan kurun waktu 2013-2017 dalam satuan miliar rupiah. Dan data lain yang berkaitan dengan penelitian ini, yang diperoleh dari Badan Pusat Statistik (BPS) dan instansi lainnya.

Provinsi Jawa Timur sebagai tempat dilakukan penelitian, dengan tahun data berkisar tahun 2013-2017. Data diambil pada kabupaten atau kota di Provinsi Jawa Timur. Sedangkan sektor industri manufaktur berdasar 16 subsektor lapangan usaha/industri, yaitu;

Tabel 1. Subsektor Industri Manufaktur

\begin{tabular}{cl}
\hline $\begin{array}{c}\text { Kode } \\
\text { Industri }\end{array}$ & \multicolumn{1}{c}{ Lapangan Usaha/Industri } \\
\hline 1 & Industri Batubara dan Pengilangan Migas \\
2 & Industri Makanan dan Minuman \\
3 & Industri Pengolahan Tembakau \\
4 & Industri Tekstil dan Pakaian Jadi \\
5 & Industri Kulit, Barang dari Kulit dan Alas Kaki \\
6 & Industri Kayu, Barang dari Kayu dan Gabus dan \\
7 & Barang Anyaman dari Bambu, Rotan dan Sejenisnya \\
8 & Industri Kertas dan Barang dari Kertas; Percetakan \\
9 & Industri Kimia, Farmasi dan Obat Tradisional \\
10 & Industri Barang Galian bukan Logam \\
11 & Industri Logam Dasar \\
12 & Industri Barang Logam; Komputer, Barang \\
& Elektronik, Optik; dan Peralatan Listrik
\end{tabular}


EKONOMIKAWAN : Jurnal Ilmu Ekonomi dan Studi Pembangunan

I55N : $1693-7600$ (print), 155N : 2598-0157 (Online), hutp://fumal_umstiacid//index.php/ekawan

\begin{aligned} & 13 Industri Mesin dan Perlengkapan \\ & 14 Industri Alat Angkutan \\ & 15 Industri Furnitur \\ & 16 $\begin{array}{l}\text { Industri Pengolahan Lainnya; Jasa Reparasi dan } \\ \text { Pemasangan Mesin dan Peralatan }\end{array} \\ &$\hline\end{aligned}

Sumber: BPS, 2018.

Digunakan 4 metode analisis dalam penelitian ini, 2 metode untuk spesialisasi dan 2 untuk konsentrasi spasial. Spesialisasi industri manufaktur dapat dilihat dari besaran indeks spesialisasi Krugman dan indeks spesialisasi bilateral. Keduanya menganalisis kesamaan struktur industri manufaktur suatu wilayah dengan wilayah benchmark dan antar wilayah dalam mengukur tingkat kekuatan spesialisasi pada wilayah yang dianalisis.

$$
\mathrm{K}_{\mathrm{SPEC}}=\sum_{S=1}^{N}\left\lceil V_{i}^{S}-V^{S}\right\rceil
$$

Dimana $V_{i}^{S}$ merupakan share PDRB industri manufaktur sub sektor $S$ terhadap PDRB industri manufaktur secara keseluruhandi kota $I V^{S}=$ share PDRB industri manufaktur sub sektor $\mathrm{S}$ terhadap PDRB industri manufaktur secara keseluruhan di Jawa Timur. $V_{i}^{S}$ dapat dirumuskan sebagai berikut;

$$
V_{i}^{S}=\frac{P D R B_{i}^{S}}{P D R B_{I}}
$$

Dimana, $P D R B_{i}^{S}$ merupakan PDRB industri manufaktur sub sektor $S$ di kota $i$, sedangkan $P D R B_{I}$ yaitu, PDRB industri manufaktur secara keseluruhan di kota $I$ Sedangkan, $V^{S}$ dapat dirumuskan sebagai berikut;

$$
V^{S}=\frac{P D R B^{S}}{P D R B}
$$

Dimana: $P D R B^{S}$ merupakan PDRB industri manufaktur sub sektor $S$ di Jawa Timur dan $P D R B$ merupakan PDRB industri manufaktur secara keseluruhan di Jawa Timur.

LQ atau bisa juga disebut Hoover-Balassa koefisien merupakan pendekatan yang paling sering digunakan dalam menganalisis spesialisasi. Pendekatan ini menyatakan bahwa spesialisasi dalam industri (terutama industri manufaktur) terjadi apabila share industri pada suatu wilayah lebih besar daripada share industri pada wilayah agregat. Sejalan dengan pendapat Lafourcade dan Mion (2003), yang menyatakan bahwa konsentrasi industri akan terjadi pada suatu lokasi dimana share PDRB untuk industri tersebut lebih besar daripada share industri secara agregat.

$$
L Q=\frac{V_{i}^{S}}{V^{S}}
$$

Nilai LQ $>1$ menunjukkan bahwa subsektor $\mathrm{S}$ terspesialisasi secara relatif di wilayah i. Berdasarkan teori basis, dan sebaliknya apabila LQ $<1$ maka subsektor $\mathrm{S}$ tidak terspesialisasi di daerah tersebut (bendhavid-Val, 1991).

Indeks Herfindahl merupakan salah satu pendekatan yang digunakan untuk menganalisis konsentrasi spasial. Pendekataan ini menunjukkan distribusi lokasi subsektor $\mathrm{S}$ industri manufaktur di wilayah analisis, dalam penelitian ini Jawa Timur. Nilai indeks herfindahl berkisar antara 0 dan 1 . Jika nilai indeks herfindahl semakin mendekati nol maka subsektor $\mathrm{S}$ industri manufaktur di wilayah analisis tersebar secara merata. Sebaliknya jika nilai indeks herfindahl semakin mendekati 1 maka distribusi lokasi dari subsektor S industri manufaktur tidak merata dan terkonsentrasi hanya di beberapa wilayah (kabupaten atau kota) saja. Indeks herfindahl dirumuskan sebagai berikut:

$$
\mathrm{H}^{\mathrm{S}}=\sum_{i=1}^{M}\left(S_{i}^{S}\right)^{2}
$$


Dimana, $S_{i}^{S}$ merupakan PDRB industri manufaktur subsektor $i$ pada seluruh kabupaten atau kota di Jawa Timur dan $\mathrm{M}$ adalah wilayah yang dianalisis.

Indeks Elisson Glaeser juga merupakan pendekatan yang menunjukkan efek dari konsentrasi spasial.

$$
\begin{aligned}
& \mathrm{g}_{\mathrm{EG}}=\sum_{i=1}^{M}\left(S_{i}^{S}-X_{i}\right)^{2} \\
& \mathrm{H}=\sum_{i=1}^{M} \frac{1}{M}\left(S_{i}^{S}\right)^{2} \\
& \mathrm{G}_{\mathrm{EG}}=\frac{g_{E G}}{1-\sum_{i=1}^{M} X_{i}^{2}} \\
& y_{E G}=\frac{G_{E g}-H}{1-H}
\end{aligned}
$$

Dimana. $X_{i}$ merupakan share PDRB kabupaten atau kota terhadap industri manufaktur pada wilayah Provinsi Jawa Timur, gEG adalah Gini lokasional yang menunjukkan tingkat konsentrasi spasial dan spesialisasi di beberapa wilayah (kabupaten atau kota), $\mathrm{H}$ adalah Firm size herfindahl yang menunjukkan distribusi pada industri. $\mathrm{G}_{\mathrm{EG}}$ atau yang biasa disebut dengan raw concentration menunjukkan besarnya kekuatan agglomerasi yang mendorong konsentrasi spasial $\mathrm{y}_{\mathrm{EG}}$ adalah indeks Elisson-Glaeser yang menunjukkan besaran Natural advantage dan Knowledge spillover.

Ellison Glaeser menyatakan bahwa jika nilai $\mathrm{y}_{\mathrm{EG}}$ dibawah 0,02 maka menunjukkan dispersi dalam kata lain tidak terkonsentrasi. Sedangkan nilai $\mathrm{y}_{\mathrm{EG}}$ diatas 0,05 maka terdapat aglomerasi yang dipengaruhi oleh natural advantage dan knowledge spillover.

\section{HASIL DAN PEMBAHASAN \\ Hasil Analisis Data \\ Spesialisasi}

a) Indeks Spesialisasi Krugman

Tabel 2. Indeks Spesialisasi Krugman $\left(\mathrm{K}_{\mathrm{SPEC}}\right)$ Berdasarkan Kabupaten atau Kota di Jawa Timur tahun 2013-2017

\begin{tabular}{lccccc}
\hline \multicolumn{1}{c}{$\begin{array}{c}\text { Kabupaten } \\
\text { /Kota }\end{array}$} & 2013 & 2014 & 2015 & 2016 & 2017 \\
\hline Kab. Blitar & 0,536 & 0,537 & 0,523 & 0,497 & 0,489 \\
Kab. Malang & 0,448 & 0,467 & 0,456 & 0,436 & 0,432 \\
Kab. Pamekasan & 0,504 & 0,504 & 0,491 & 0,463 & 0,456 \\
Kab. Tulungagung & 0,486 & 0,492 & 0,479 & 0,449 & 0,439 \\
Kab. Tuban & 1,631 & 1,620 & 1,616 & 1,600 & 1,594 \\
Kota Kediri & 1,427 & 1,432 & 1,427 & 1,409 & 1,417 \\
Kota Surabaya & 0,329 & 0,318 & 0,306 & 0,298 & 0,279 \\
\hline
\end{tabular}

Sumber: BPS Jawa Timur, 2018, data diolah.

Berdasarkan indeks spesialisasi Krugman pada tabel 2, daerah yang memiliki nilai $\mathrm{K}_{\mathrm{SPEC}}$ semakin mendekati nol maka kabupaten atau kota tersebut memiliki struktur perekonomian yang sama dengan Jawa Timur, artinya tidak memiliki spesialisasi. Sebaliknya, jika nilai $\mathrm{K}_{\mathrm{SPEC}}$ mendekati 2 maka kabupaten atau kota tersebut memiliki spesialisasi atau struktur perekonomiannya berbeda dengan Jawa Timur. Tabel 2 menunjukkan hasil dari indeks spesialisasi Krugman $\left(\mathrm{K}_{\mathrm{SPEC}}\right)$ dari kabupaten atau kota di Jawa timur dari tahun 2013 sampai tahun 2017. Nilai tertinggi pada Tabel 2 diperoleh oleh Kabupaten Tuban dengan nilai 1,631 pada tahun 2013, selalu menurun menjadi 1,5941 pada tahun 2017. Data menunjukkan bahwa Kabupaten Tuban memiliki struktur perekonomian relatif berbeda serta spesialisasi yang relatif terhadap Jawa Timur. Kota Kediri memiliki nilai $\mathrm{K}_{\mathrm{SPEC}}$ sebesar 1,4268 dan mengalami kenaikan serta penurunan 
menjadi 1,4165 yang berarti Kota Kediri juga memiliki struktur perekonomian yang relaitif berbeda dan spesialisasi yang relatif.

Untuk hasil terendah diperoleh Kota Surabaya 0,3291 pada tahun 2013 dan terus menurun menjadi 0,2788 di tahun 2017. Kabupaten Malang 0,4482 pada tahun 2013 mengalami peningkatan dan turun pada tahun 2017 menjadi 0,4316. Kabupaten Tulungagung 0,4858 tahun 2013 dan menurun menjadi 0,4391 pada tahun 2017. Hasil tersebut menunjukkan bahwa struktur perekonomian Kota Surabaya relatif sama dengan Jawa Timur yang menandakan bahwa Kota Surabaya tidak terspesialisasi.

b) Location Quotient (LQ)

Tabel 3. Nilai LQ Jawa Timur 2013-2017

\begin{tabular}{cccccc}
\hline Kode Industri & 2013 & 2014 & 2015 & $2016^{*}$ & $2017^{* *}$ \\
\hline 1 & 0,0147 & 0,0132 & 0,0136 & 0,0151 & 0,016 \\
2 & 1,1068 & 1,0868 & 1,0769 & 1,0458 & 1,0406 \\
3 & 6,3671 & 6,0559 & 5,8346 & 5,8832 & 5,9792 \\
4 & 0,2473 & 0,2516 & 0,2639 & 0,2749 & 0,2714 \\
5 & 1,0969 & 1,0703 & 1,023 & 0,9711 & 1,074 \\
6 & 1,9104 & 1,8534 & 1,8073 & 1,6954 & 1,7481 \\
7 & 1,3893 & 1,2823 & 1,3112 & 1,3354 & 1,3219 \\
8 & 1,1024 & 1,1002 & 1,0368 & 0,9454 & 0,9291 \\
9 & 1,2521 & 1,2833 & 1,2337 & 1,2734 & 1,2107 \\
10 & 1,2545 & 1,258 & 1,2202 & 1,1201 & 1,2568 \\
11 & 1,0351 & 1,1192 & 0,9972 & 1,0399 & 1,0691 \\
12 & 0,5194 & 0,5276 & 0,4962 & 0,4548 & 0,4377 \\
13 & 0,1732 & 0,1486 & 0,1428 & 0,1329 & 0,121 \\
14 & 0,1313 & 0,1267 & 0,125 & 0,1173 & 0,1099 \\
15 & 2,5083 & 2,5397 & 2,4075 & 2,405 & 2,282 \\
16 & 1,2049 & 1,1786 & 1,1058 & 1,1112 & 1,1315 \\
\hline
\end{tabular}

Sumber: BPS, 2018, data diolah.

Tabel 3 menunjukkan hasil dari analisis LQ di Provinsi Jawa Timur dalam rentang waktu 2013-2017. Dapat dilihat bahwa hasil tertinggi didapat oleh sektor industri pengolahan tembakau, meskipun sempat menurun trennya pada tahun $2013-2015(6,3671$ menjadi 5,8346) namun nilainya mulai meningkat pada tahun 2016 (5.8832) dan 2017 $(5,9792)$. Tingginya nilai LQ subsektor industri pengolahan tembakau ini dikarenakan oleh tingginya peranan industri pengolahan tembakau di Jawa Timur yang mencapai 23\% hingga 24\% terhadap PDRB sektor industri pengolahan, sedangkan Indonesia hanya dalam kisaran 4,12\% hingga 4,45\% saja. Hal tersebut terjadi karena banyaknya industri rokok di Jawa Timur misalnya, beberapa industri rokok terbesar di Indonesia PT. HM Sampoerna yang berada di Kabupaten Pasuruan dan Kota Surabaya, PT. Gudang Garam Tbk. yang berlokasi di Kota Kediri, serta PT Bentoel Internasional Investama yang berlokasi di Kabupaten Malang. Kemudian, sektor industri furnitur dengan nilai LQ 2,5083 trennya menurun menjadi 2,2820, hal ini disebabkan oleh meningkatnya share industri furnitur Indonesia sedangkan untuk Jawa Timur terus menurun. Selain itu, Jawa Timur juga merupakan salah satu daerah dengan ekspor barang furnitur tertinggi di Indonesia.

Sektor Industri Kayu, Barang dari Kayu dan Gabus dan Barang Anyaman dari Bambu, Rotan dan Sejenisnya memiliki nilai LQ tahun 2013 sebesar 1,9104 dan terus 
menurun hingga 1,6954 pada tahun 2016 dan meningkat lagi sebesar 1,7481 di tahun 2017. Industri Kertas dan Barang dari Kertas; Percetakan dan Reproduksi Media Rekaman dengan nilai LQ 1,3893 pada tahun 2013 dan berfluktuasi nilainya menjadi 1,3219 di tahun 2017. Industri Barang Galian bukan Logam memiliki nilai LQ 1,2545 pada tahun 2013 dan berfluktuasi menjadi 1,2568 di tahun 2017. Industri Karet, Barang dari Karet dan Plastik 1,2521 di tahun 2013 berfluktuasi menjadi 1,2107. Industri Pengolahan Lainnya; Jasa Reparasi dan Pemasangan Mesin dan Peralatan 1,2049 berfluktuasi menjadi 1,1315 di tahun 2017. Industri Makanan dan Minuman 1,1068 terus menurun menjadi 1,0406. Untuk Industri Kimia, Farmasi dan Obat Tradisional dan Industri Kulit, Barang dari Kulit dan Alas Kaki hanya memiliki nilai LQ lebih dari satu pada tahun 2013-2015. Dan Industri Logam Dasar hanya pada tahun 2015 saja nilai LQnya tidak lebih dari 1.

\section{Konsentrasi Spasial}

a) Indeks Herfindahl

Tabel 4. Indeks Herfindahl menurut Subsektor Industri Manufaktur Kabupaten atau Kota di Jawa Timur Tahun 2013-2017

\begin{tabular}{cccccc}
\hline Kode Industri & 2013 & 2014 & 2015 & 2016 & 2017 \\
\hline 1 & 0,4752 & 0,4693 & 0,4641 & 0,4663 & 0,4694 \\
2 & 0,1122 & 0,1130 & 0,1132 & 0,1132 & 0,1131 \\
3 & 0,3898 & 0,3837 & 0,3835 & 0,3808 & 0,3794 \\
4 & 0,1332 & 0,1337 & 0,1337 & 0,1342 & 0,1338 \\
5 & 0,1726 & 0,1715 & 0,1730 & 0,1733 & 0,1730 \\
6 & 0,1078 & 0,1091 & 0,1090 & 0,1090 & 0,1080 \\
7 & 0,2674 & 0,2679 & 0,2689 & 0,2701 & 0,2709 \\
8 & 0,1744 & 0,1759 & 0,1771 & 0,1785 & 0,1792 \\
9 & 0,2015 & 0,2039 & 0,2021 & 0,2017 & 0,1994 \\
10 & 0,3598 & 0,3549 & 0,3566 & 0,3650 & 0,3607 \\
11 & 0,2497 & 0,2444 & 0,2427 & 0,2428 & 0,2429 \\
12 & 0,2240 & 0,2257 & 0,2225 & 0,2215 & 0,2160 \\
13 & 0,3618 & 0,3614 & 0,3566 & 0,3602 & 0,3490 \\
14 & 0,2154 & 0,2157 & 0,2126 & 0,2110 & 0,2059 \\
15 & 0,1273 & 0,1299 & 0,1307 & 0,1304 & 0,1289 \\
16 & 0,1091 & 0,1067 & 0,1068 & 0,1064 & 0,1069 \\
\hline
\end{tabular}

Sumber: BPS Jawa Timur, 2018, data diolah.

Tertinggi kedua yaitu subsektor industri pengolalahan tembakau dengan nilai indeks Herfindahl 0,3898 pada tahun 2013 dan terus menurun hingga 0,3794 di tahun 2017. Subsektor industri pengolahan tembakau di Jawa Timur terkonsentrasi di Kota Kediri dengan kontribusi kisaran 58\%-60\% di rentang waktu 2013-2017. Besarnya kontribusi Kota Kediri ini tidak terlepas dengan adanya salah satu industri rokok terbesar di Indonesia yaitu, PT. Gudang Garam Tbk, selain itu PT. Gudang Garam Tbk. juga berperan dalam kehidupan masyarakat Kota Kediri dalam aspek sosial dan ekonomi,

Tertinggi ketiga, yaitu subsektor industri mesin dan perlengkapan dengan nilai indeks Herfindahl 0,3618 pada tahun 2013 berfluktuasi dan menurun menjadi 0,3490 pada tahun 2017. Subsektor ini terkonsentrasi di dua Kabupaten atau Kota yaitu, Kota Surabaya dan Kabupaten Pasuruan. Kota Surabaya dengan kisaran 52\%-54\%, ini dikarenakan banyaknya pemasok mesin berat yang berada di Kota Surabaya. Sedangkan Kabupaten 
Pasuruan pada kisaran 19\%-20\%, sama halnya dengan Kota Surabaya, di Kabupaten pasuruan banyak pemasok dan distributor mesin-mesin seperti mesin jahit, mesin untuk konveksi, mesin border, dan lain-lain.

Posisi ke empat, subsektor industri barang galian bukan logam dengan nilai indeks Herfndahl 0,3598 pada tahun 2013 terus meningkat hingga 0,3607 pada tahun 2017. Subsektor industri barang galian bukan logam terkonsentrasi di Kabupaten Tuban dengan konsentrasi kisaran 57\%-58\%. Hampir seluruh wilayah Kabupaten Tuban berpotensi untuk kegiatan pertambangan membuat kontribusinya tinggi pada subsektor ini. Potensi tambang yang berada di Kabupaten Tuban yaitu, batu kapur, fosfat, tanah liat, dolomite, ball clay, pedel, pasir kwarsa, dan sebagainya.

Posisi ke lima terdapat subsektor industri kertas dan barang dari kertas; percetakan dan reproduksi media rekaman. Subsektor industri ini terkonsentrasi di Kabupaten Sidoarjo dengan tingkat konsentrasi pada kisaran 48\% dalam kurun waktu 2013-2017. PT Pabrik Kertas Tjiwi Kimia Tbk merupakan salah satu pabrik salah satu industri kertas yang mendorong tingginya kontribusi subsektor industri kertas dan barang dari kertas; percetakan dan reproduksi media rekaman Kabupaten Sidoarjo.

b) Indeks Ellison Glaeser

Tabel 5. Indeks Ellison Glaeser Subsektor Industri Manufaktur Menurut Kabupaten atau Kota di Jawa Timur 2013-2017

\begin{tabular}{cccccc}
\hline Kode Industri & 2013 & 2014 & 2015 & 2016 & 2017 \\
\hline 1 & 0,4866 & 0,4794 & 0,4732 & 0,4769 & 0,4869 \\
3 & 0,5313 & 0,5252 & 0,525 & 0,5219 & 0,5204 \\
7 & 0,3773 & 0,3785 & 0,3797 & 0,381 & 0,3839 \\
10 & 0,4808 & 0,4758 & 0,4777 & 0,4875 & 0,4843 \\
13 & 0,4953 & 0,4956 & 0,4903 & 0,4941 & 0,4819 \\
\hline
\end{tabular}

Sumber: BPS Jawa Timur, 2018, data diolah.

Hasil dari indeks Ellison-Glaeser pada Tabel 5, menunjukkan bahwa seluruh subsektor industri manufaktur di Jawa Timur tahun 2013-2017 terkonsentrasi secara spasial yang disebabkan oleh natural advantage dan knowledge spillover. Untuk yang tertinggi sektor industri pengolahan tembakau sebesar 0,5313 pada tahun 2013 terus menurun angkanya menjadi 0,5204 pada tahun 2017. Penurunan serta peningkatan nilai indeks Elisson Glaeser ini menunjukkan bahwa peranan dari natural advantage dan knowledge spillover juga menurun dan meningkat.

\section{Pembahasan \\ Spesialisasi}

Berdasarkan analisis indeks spesialiasasi Krugman $\left(\mathrm{K}_{\mathrm{SPEC}}\right)$ daerah yang memiliki spesialisasi atau struktur industri manufaktur yang berbeda dengan Provinsi Jawa Timur yaitu Kabupaten Tuban dan Kota Kediri. Perbedaan ini dikarenakan 2 daerah ini hanya mengandalkan 1 subsektor saja pada struktur PDRB sektor industri manufaktur yaitu, industri barang galian bukan logam untuk Kabupaten Tuban dan industri pengolahan tembakau untuk Kota Kediri. Sedangkan daerah yang memiliki kesamaan struktur industri manufaktur dengan Provinsi Jawa Timur yaitu Kota Surabaya, Kabupaten Malang, Kabupaten Pamekasan, Kabupaten Tulungaung dan Kabupaten Blitar. Penting untuk mengetahui struktur industri manufaktur suatu daerah karena berguna untuk mengetahui karakteristik industri manufaktur masing-masing daerah, karakteristik tersebut digunakan 


\section{EKONOMIKAWAN : Jurnal Ilmu Ekonomi dan Studi Pembangunan}

I55N : $1693-7600$ (print), 155N : 2598-0157 (Online), hutp://fumal_umstiacid//index.php/ekawan

sebagai sarana informasi suatu industri untuk melakukan translokasi. Suatu industri akan bertranslokasi jika lokasi tujuan translokasi dengan lokasi terdahulu memiliki struktur industri manufaktur dan karakteristik yang tidak jauh berbeda sehingga industri tersebut tidak perlu melakukan adapatasi dengan lokasi baru tersebut (Ellisson dan Glaeser, 1997) Translokasi sendiri harus didukung oleh tersedianya infrastruktur yang memadai. Sedangkan indeks spesialisasi bilateral digunakan untuk memberikan informasi kepada setiap daerah guna mengetahui sebaiknya dengan daerah mana sebaiknya bekerja sama.

Berdasarkan analisis Location Quotient (LQ) atau indeks Hoover-Balassa, Provinsi Jawa Timur 2013 dan 2014 terspesialisasi pada 11 subsektor industri manufaktur yaitu, subsektor industri makanan dan minuman (2) subsektor ini merupakan sektor yang dijadikan unggulan di Jawa Timur. Jawa Timur merupakan salah satu daerah pemasok pada sektor ini di Indonesia hal ini dibuktikan dengan tingginya ekspor Jawa Timur ke berbagai daerah. Subsektor industri pengolahan tembakau (3), sektor ini dijadikan sektor unggulan di Jawa Timur alasannya karena banyaknya daerah lahan yang ditanami tembakau serta banyaknya industri rokok baik kecil maupun besar, terdapat 2 perusahaan rokok besar yang menguasai pangsa pasar rokok di Indonesia yaitu, PT. HM SAMPOERNA yang berlokasi di Kota Surabaya dan Kabupaten Pasuruan dan PT. Gudang Garam Tbk. yang berada di Kota Kediri, selain itu tingginya ekspor tembakau Jawa Timur yang selalu tinggi setiap tahunnya membuat kontribusi Jawa Timur pada sektor ini sangat tinggi meskipun masih dibawah sektor industri makanan dan minuman tetapi jika dibandingkan dengan provinsi lain, Jawa TImur merupakan yang tertinggi pada sektor ini. Subsektor industri kulit, barang dari kulit dan alas kaki (5), meski bukan sektor yang diunggulkan Jawa Timur namun nyatanya sektor ini memiliki kontribusi tinggi jika dibandingkan dengan provinsi lain hal ini dikarenakan pada subsektor ini Indonesia hanya bertumpu pada 2 provinsi yaitu, Provinsi Jawa Barat dan Jawa Timur saja, Jawa Barat dengan industri besarnya sedangkan di Jawa Timur industri sedang. Berjamurnya subsektor ini di Jawa Timur membuat ekspor tinggi hingga ke Uni Eropa dan negara lain yang mendorong tingginya PDRB pada sektor ini.

Subsektor industri kayu, barang dari kayu dan gabus dan barang anyaman dari bambu, rotan dan sejenisnya (6), pada sektor ini Jawa Timur merupakan proinsi dengan kontribusi terbesar di Indonesia. Industri ini di Jawa Timur tebilang cukup bangyak mencapai 986 perusahaan dan yang berorientasi ekspor terdapat 205 perusahaan dengan begitu ekspor pada subsektor ini sangat tinggi dan berkontribusi sangat besar. Subsektor industri kertas dan barang dari kertas; percetakan dan reproduksi media rekaman (7) pada subsektor ini Jawa Timur merupakan salah satu dari 5 pengekspor tertinggi di Indonesia sehingga menjadikan subsektor ini spesialisasi Provinsi Jawa Timur. Subsektor industri kimia, farmasi dan obat tradisional (8), subsektor ini merupakan salah satu sektor yang dijadikan unggulan di Jawa Timur, untuk skala nasional Jawa Timur masih berada dibawah Provinsi Jawa Barat tetapi kontribusinya terbilang tinggi.

Subsektor industri barang galian bukan logam (10), di Provinsi Jawa Timur meski bukan daerah yang diprioritaskan untuk aktivitas tambang namun nyatanya banyak mengandung barang tambang didalam tanahnya, nyatanya banyak perusahaan-perusahaan yang beroperasi di Jawa Timur seperti, PT. Semen Gresik yang membutuhkan batu gamping sebagai bahan dasar diambil dari beberapa kabupaten atau kota di Jawa Timur seperti, Kabupaten Tuban, Kabupaten Gresik dan lain-lain. Tambang emas tumpeng pitu yang berada di Kabupaten Banyuwangi merupakan salah satu tambang emas yang cukup besar di Indonesia dan masih banyak potensi tambang lain yang tersebar di kabupaten atau kota yang ada di Jawa Timur. Subsektor industri furnitur (15), pada subsektor ini Jawa

Copyright@2020, Ekonomikawan : Jurnal IImu ekonomi dan Studi Pembangunan. This is an open access article under the 
Timur merupakan pemasok dari berbagai daerah, tercatat untuk pasar global Jawa timur sudah merambah sampai Amerika, Eropa, Asia Tengah dan ASEAN yang dapat menggenjot kontribusi sektor ini terhadap PDB Indonesia yang membuat Jawa Timur terspesialisasi pada subsektor ini.

Subsektor industri karet, barang dari karet dan plastik (9), Subsektor industri logam dasar (11), dan subektor industri pengolahan lainnya; jasa reparasi dan pemasangan mesin dan peralatan (16). Pada tahun 2015 menjadi 10 spesialisasi berkurang 1 yaitu, subsektor industri logam dasar, pada tahun 2016 spesialisasinya berkurang lagi menjadi 9 subsektor, berkurangnya spesialisasi ini dikarenakan 2 subsektor yaitu, subsektor industri kulit, barang dari kulit dan alas kaki (5) dan industri kimia, farmasi dan obat tradisional (8) memiliki nilai LQ dibawah 1 dan pada tahun 2017 dengan kembalinya subsektor industri kulit, barang dari kulit dan alas kaki (5) dengan nilai LQ lebih 1 menjadikan spesialisasi industri manufaktur Provinsi Jawa Timur menjadi 10 subsektor. Banyaknya spesialisasi subsektor industri manufaktur di Jawa Timur ini dikarenakan kurang meratanya pembangunan industri di Indonesia sehingga kontribusi seluruh subsektor industri Provinsi Jawa Timur merupakan salah satu tertinggi bahkan terdapat yang tertinggi di Indonesia.

Ada 5 provinsi yang berkontribusi pada PDB sektor industri manufaktur Indonesia, 4 provinsi berasal dari Pulau Jawadan hanya terdapat 1 provinsi yang berasal dari luar Pulau Jawa, artinya pembangunan industri di Indonesia terlalu fokus di Pulau Jawa saja sehingga membuat provinsi di Pulau Jawa memiliki banyak spesialisasi subsektor industri manufaktur. Serta berkurang dan bertambahnya kabupaten atau kota yang terspesialisasi itu disebabkan oleh meningkatkan peranan kabupaten atau kota atau sektor lain pada subsektor industri manufaktur yang dapat menyebabkan hasil nilai LQ juga menurun.

Hasil dari penelitian ini sejalan dengan penelitian dari Landiyanto (2005) yang menyatakan bahwa spesialisasi industri manufaktur subsektor industri makanan, minuman dan tembakau (ISIC 3.1), subsektor industri tekstil, pakaian jadi dan kulit (ISIC 3.2) dan subsektor industri barang galian non logam, kecuali minyak bumi dan batu bara (ISIC 3.6). dan juga penelitian Saputra (2015) yang menyatakan bahwa spesialisasi industri manufaktur (usaha kecil menengah) Provinsi Jawa Timur yaitu, subsektor industri kayu, dan industri makanan, minuman, dan tembakau. Namun terdapat tambahan subsektor pada penelitian ini dikarenakan perbedaan jumlah subsektor yang digunakan serta tahun penelitiannya.

\section{Konsentrasi Spasial}

Aiginger dan Hansberg (dalam Tarigan, 2005) berpendapat bahwa terdapat perbedaan makna anatara spesialisasi dengan konsentrasi spasial. Konsentrasi spasial dimaknai sebagai regional share yang menunjukkan distribusi lokasional dari suatu industri. Menurut hasil dari analisis Indeks Herfindahl industri manufaktur di Provinsi Jawa Timur terkonsentrasi secara spasial di beberapa kabupaten atau kota yaitu, Kabupaten Bojonegoro dan Kabupaten Gresik terkonsentrasi pada subsektor industri batubara dan pengilangan migas. Dimana, Kabupaten Bojonegoro memiliki Blok Cepu dan Pertamina beserta anak perusahaannya yang merupakan pemasok migas di Indonesia. Hal ini dapat dilihat pada besaran distribusi lokasional, bahwa Kabupaten Bojonegoro berperan sebesar 40,89\%, 41,87\%, 42,38\%, 41,56\%, 41,50\%. Untuk Kabupaten Gresik sendiri memiliki industri hulu migas yang strategis, selain itu Kabupaten Kediri merupakan pusat berkumpulnya semua SKK migas di Indonesia, seperti PGN Saka, Pertamina WMO, dan PJB yang mengeksplorasi migas di Kabupaten Gresik. Hal ini yang menyebabkan 
distribusi lokasional subsektor industri batubara dan pengilangan migas kota Gresik tinggi yaitu sebesar, 55,48\%, 54,19\%, 53,30\%, 54,14\%, 54,48\% dalam kurun waktu 2013-2017.

Kota Kediri merupakan daerah yang terkonsentrasi pada subsektor industri pengolahan tembakau. Distribusi lokasional subsektor industri pengolahan tembakau Kota Kediri $60,01 \%$ tahun $2013,59,34 \%$ tahun $2014,59,30 \%$ tahun $2015,59,02$ tahun 2016 dan $58,82 \%$ pada tahun 2017. Terkonsentrasinya subsektor industri pengolahan tembakau ini tidak terlepas dari peranan PT. Gudang Garam Tbk. yang berperan penting dalam segala aspek kehidupan di Kota Kediri. Subsektor mesin dan perlengkapan terkonsentrasi secara spasial di Kota Surabaya dan Kabupaten Pasuruan. kedua daerah ini merupakan daerah pemasok mesin-mesin baik mesin berat maupun mesin-mesin ringan di Indonesia bahkan ke luar negeri. Kota Surabaya merupakan pemasok mesin-mesin berat. Sedangkan untuk Kabupaten Pasuruan pemasok atau distributor mesin-mesin alat konveksi seperti mesin jahit, dan mesin bordir.

Subsektor industri kertas dan barang dari kertas; percetakan dan reproduksi media rekaman. Subsektor industri ini terkonsentrasi di Kabupaten Sidoarjo dengan tingkat konsentrasi pada kisaran 48\% dalam kurun waktu 2013-2017. PT Pabrik Kertas Tjiwi Kimia Tbk. merupakan salah satu pabrik salah satu industri kertas yang mendorong tingginya kontribusi subsektor industri kertas dan Barang dari kertas; percetakan dan reproduksi media rekaman Kabupaten Sidoarjo. Kota Tuban industrinya terkonsentrasi pada subsektor industri barang galian bukan logam, hampir seluruh wilayah Kabupaten Tuban berpotensi untuk dilakukannya aktivitas tambang. Potensi tambang yang dimiliki Kabupaten Tuban antara lain batu kapur, fosfat, tanah liat, dolomic, ball clay, pedel, pasir kwarsa dan sebagainya. Kawasan industri Tuban yang dijuga dikelola oleh PT. Kawasan Industri Gresik ini memang ditujukan untuk barang galian non. Kawasan industri ini dibagi menjadi 3 zona, yaitu zona 1 yang difokuskan untuk industri keramik, zona 2 difokuskan untuk industri genteng, gypsum dan eternity, semen, keramik, zona 3 difokuskan pada industri batu kapur dan keramik. Selain itu Kabupaten Tuban memiliki 4 pabrik yang menggunakan bahan dasar barang galian non logam untuk proses produksinya, seperti PT. Semen Gresik, PT. Trans Pasific Petrochemical Indotama, PT. Holcim Indonesia, dll. Konsentrasi spasial industri manufaktur Provinsi Jawa Timur didukung oleh peranan natural advantage dan knowledge spilloverberdasarkan indeks Eliison-Glaeser.

Hasil dari konsentrasi spasial industri manufaktur pada penelitian ini sesuai dengan penelitian yang dilakukan Landiyanto (2005) yang mana hasilnya industri manufaktur Provinsi Jawa Timur terkonsentrasi Kota Surabaya, Kabupaten Gresik, Kabupaten Sidoarjo, Kota Kediri, Kabupaten Pasuruan dan Kota Malang. Perbedaan hasilnya pada penelitian ini Kota Malang tidak terkonsentrasi namun terdapat tambahan yaitu, Kabupaten Bojonegoro dan Kabupaten Tuban. Perubahan ini dikarenakan selisih tahun penelitian Landiyanto dan penelitian ini berkisar 10-20 tahunan dan selama kurun waktu tersebut tentunya pemerintah Provinsi Jawa Timur melakukan pembangunan yang mengakibatkan hasil penelitian berbeda.

Hirchman (1958) mengatakan bahwa dalam suatu wilayah yang lebih luas (Jawa Timur) memiliki pusat pertumbuhan (center growth) dan daerah terbelakang (hinterland). Kota Surabaya yang merupakan pusat pertumbuhan ekonomi (center growth) di Jawa Timur memiliki infrastruktur yang cukup lengkap seperti bandara udara, jalan yang dapat terhubung ke seluruh daerah, bandara udara serta teknologi yang memadai untuk memperoleh informasi sehingga dapat mempermudah suatu industri untuk medistribusikan output dan dapat menghemat biaya produksi. Industri cenderung terkonsentrasi di daerah pusat pertumbuhan dikarenakan mendapat manfaat seperti bentuk penghematan dan 
kemudahan dengan adanya infrastruktur yang lengkap, hal tersebut dapat memperluas daerah pertumbuhan ke daerah hinterland (triking down effect) (Keban, 1995). Di Jawa Timur yang merupakan daerah hinterland yaitu, kabupaten Gresik, Kabupaten Sidoarjo dan Kabupaten Pasuruan. Ketiga kabupaten ini terkena imbas dari aktivitas ekonomi maupun industri Kota Surabaya. Glaeser dan Kohlase (2003) mengatakan suatu industri cenderung berkonsentrasi pada daerah atau wilayah yang memiliki infrastruktur lengkap yang memberikan manfaat kepada industri berupa penghematan dan kemudahan untuk mendistribusikan barang dan jasa hasil produksi. Kota Surabaya merupakan daerah yang memiliki infrastruktur paling lengkap di Jawa Timur seperti, bandara udara, jalan-jalan utama yang dapat menghubungkan Kota Surabaya dengan daerah di sekitarnya, pelabuhan dan sarana informasi serta telekomunikasi yang tentunya berimbas kepada daerah sekitarnya seperi Kabupaten Gresik, Kabupaten Sidoarjo dan Kabupaten Pasuruan. Selain terkena imbas dari infrastruktur ketiga kabupaten ini juga terletak di jalur utama pantai utara (Pantura) dan juga memiliki jalan tol yang memudahkan distribusi barang dari industri dan dapat menghemat biaya produksi. Hal ini sejalan dengan penelitian Yunitasari dan Firmansyah (2019) yang menyatakan bahwa Kabupaten Pasuruan, Kabupaten Sidoarjo, dan Kota Surabaya, termasuk kabupaten atau kota yang pertumbuhannya cepat jika dibandingkan dengan rata-rata pertumbuhan ekonomi dan pendapatan per kapita Provinsi Jawa Timur. Penentuan lokasi industrinya sesuai dengan Least Cost Theory yang dipelopori oleh Alfred Weber yang mengatakan bahwa industri akan menentukan lokasi berdasarkan 3 faktor yaitu, biaya transport, perbedaan upah dan aglomerasi. Maka dengan menekan biaya transportasi industri dapat menghemat biaya produksi dan juga memaksimalkan laba.

The industrial district Cluster atau yang dikenal dengan Marshalian industrial district Jawa Timur hanya ditemukan di Kota Kediri, dimana subsektor industri pengolahan tembakau terkonsentrasi secara spasial dan juga terspesialisasi. Sedangkan untuk the industrial complex cluster banyak ditemukan di hampir seluruh kabupaten atau kota Jawa Timur yang mana terdapat kerja sama antar perusahaan maupun daerah untuk membangun industrinya. The social network hampir tidak ditemukan di Jawa Timur karena konsentrasi industri secara spasial tidak terjadi secara alami melainkan terdapat campur tangan pemerintah dan investor dalam pembentukan klasternya.

\section{SIMPULAN}

Berdasarkan hasil analisis indeks spesialisasi Krugman daerah yang terspesialisasi yaitu, Kabupaten Tuban dan Kota Kediri, sedangkan daerah yang memiliki kesamaan struktur industri manufaktur dengan Provinsi Jawa Timur yaitu Kota Surabaya, Kabupaten Malang, Kabupaten Pamekasan, Kabupaten Tulungaung dan Kabupaten Blitar. Dan berdasarkan hasil analisis Location Quotient (LQ) atau indeks Hoover-Balassa Industri manufaktur Provinsi Jawa Timur terspesialisasi pada 11 subsektor yaitu, subsektor industri makanan dan minuman (2), industri pengolahan tembakau (3), industri kulit, barang dari kulit dan alas kaki (5), industri kayu, barang dari kayu dan gabus dan barang anyaman dari bambu, rotan dan sejenisnya (6), industri kertas dan barang dari kertas; percetakan dan reproduksi media rekaman (7), industri kimia, farmasi dan obat tradisional (8), industri karet, barang dari karet dan plastic (9), industri barang galian bukan logam (10), industri logam dasar (11), industri furnitur (15) dan industri pengolahan lainnya; jasa reparasi dan pemasangan mesin dan peralatan (16).

Berdasarkan hasil analisis Indeks Herfindahl industri manufaktur Provinsi Jawa Timur terkonsentrasi secara spasial di beberapa kabupaten atau kota yaitu, Kabupaten 


\section{EKONOMIKAWAN : Jurnal Ilmu Ekonomi dan Studi Pembangunan}

I55N : $1693-7600$ (print), 155N : 2598-0157 (Online), hutp://rumal.umstiac.id//ndex,php/ekawan

Bojonegoro dan Kabupaten Gresik pada subsektor industri batu bara dan pengilangan migas, Kota Kediri pada subsektor industri pengolahan tembakau, Kota Surabaya dan Kabupaten Pasuruan pada subsektor industri mesin dan perlengkapan, Kabupaten Sidoarjo pada subsektor industri kertas dan barang dari kertas; percetakan dan reproduksi media rekaman dan Kabupaten Tuban pada subsektor industri barang galian bukan logam. Berdasarkan hasil indeks Elisson-Glaeser Konsentrasi spasial industri manufaktur Provinsi Jawa Timur didukung oleh peranan natural advantage dan knowledge spillover.

\section{DAFTAR PUSTAKA}

Adisasmita, R.H. (2005). Dasar-Dasar Ekonomi Wilayah. Yogyakarta : Graha Ilmu.

Aiginger, K. and Hansberg, E. 2003. Specialization versus Concentration: A Notes of Theory and Evidence. SIEPR Working Paper.

Arsyad, L. (1999). Ekonomi Pembangunan. Edisi Keempat. Yogyakarta : Sekolah Tinggi Ilmu Ekonomi YKPN.

Badan Pusat Statistik. (2018). Jawa Timur dalam Angka. Surabaya: BPS

Badan Pusat Statistik. (2018). Pendapatan Nasional Indonesia 2013-2017. Jakarta : BPS

Ellison, G. dan Glaeser, E.L. (1997). "Geographic Concentration in U.S.Manufacturing Industries: A Dartboard Approach". Journal of Political Economies, 1997. Vol. 105 No.5.

Glaeser, E. and Kohlase, J, (2003), "Cities, Region and the Decline of Transport Cost". Havard Institute of Economic Research Dicussion Paper No. 2014

Hirchman, A. O. (1958). The Strategy of Economics development (Vol. 10). University of Texas: Yale University Press.

Keban, Y. (1995). Pembangunan Regional (Hand Out). Yogyakarta : Fakultas Pascasarjana UGM.

Kuncoro, Mudrajat. (2002). Analisis Spasial dan Regional: Studi Aglomerasi dan Klaster Industri Indonesia. Yogyakarta: UPP AMP YKPN.

Kuncoro, Mudrajad. (2007). Ekonomika Industri Indonesia: Menuju Negara Industri Baru 2030?. Yogyakarta: ANDI

Landiyanto, Erlangga Agustino. (2005). Spesialisasi dan Konsentrasi Spasial Industri Manufaktur di Jawa Timur. Departemen Ilmu Ekonomi Fakultas Ekonomi Universitas Airlangga.

Saputra, Adik Kurniawan. (2015). Analisis Spesialisasi Dan Konsentrasi Spasial Industri Kecil Menengah Di Jawa Timur. Universitas Jember.

Taringan, Robinson. (2005). Ekonomi Regional: Teori dan Aplikasi. Jakarta : PT Bumi Aksara.

Yunitasari, D. (2019). Achieving Self-Sufficiency Through Sugar Supply and Demand Policies (Dynamics System Approach). nternasional Journal of Scientific \& Technology Research Volume 8, Issue 03, March 2019.

Yunitasari, D. and Firmansayah, J. Z. (2019). Mapping Of Regional Inequality In East Java Province. Internasional Journal of Scientific \& Technology Research Volume 8, Issue 03, March 2019. 